\title{
Modifikasi Atau Modernisasi (?): Permainan Anak di Sekolah Kartini Semarang
}

\author{
Galuh Ambar Sasi, Emy Wuryani, Sunardi \\ galuh.ambarsasi@uksw.edu, emy.wuryani@uksw.edu, sunardi@uksw.edu \\ Pendidikan Sejarah, Fakultas Keguruan dan Ilmu Pendidikan, Universitas Kristen Satya Wacana
}

Modification Or Modernization (?):

Children's Games At The Kartini School Semarang

\begin{abstract}
This paper examines the children's playings at Kartini School Semarang. By Combining the annual reports, memorial albums, colonial magazines and newspapers, archives, literature, ego documents, then approached with history of mentality perspectives, we point out that they developed following Froebel's education system. Therefore, they integrated into the curriculum for the 1st-3rd grade, unlimited by type, philosophy, languages, or its influence on students, while the school resembled a children's playground.
\end{abstract}

Keywords: Kartini School, Children's Games, Industrial Revolution, Technology Disruption

\section{Article Info}

Received date: 6 Desember 2020
Accepted date: 19 Januari 2021

\section{PENDAHULUAN}

Ada 253 peristiwa yang dianggap sebagai hari penting di Indonesia (Anonim 2020). Salah satunya adalah 21 April. Tanggal ini penting karena merupakan peringatan kelahiran Raden Adjeng Kartini, sosok pelopor dan populer emansipasi perempuan.

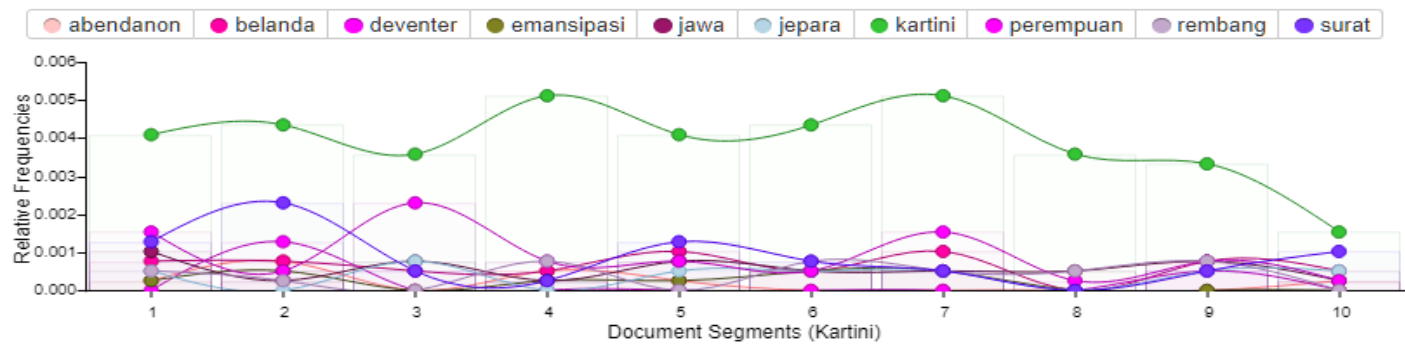

Gambar 1. Tren Hari Kartini

Keberadaan Hari Nasional 21 April dan kepopuleran tokoh Kartini ini mendorong penulis untuk melakukan dua percobaan. Pertama, pengecekan terhadap hasil pencarian mesin pencarian Google terkait tiga hal, yaitu: Hari Kartini, 21 April, Kartini, juga R.A. Kartini. Kegiatan ini menghasilkan temuan bahwa hasil pencarian terhadap keempat kata tersebut masing-masing adalah 16.100.000 (0,4 detik), 3.730.000.000 (0,41 detik), 17.600 .000 (0,69 detik), serta 4.840 .000 (0.58 detik). Kedua, pelacakan terhadap topik bahasa utama di hari istimewa ini melalui aplikasi analisis scopus voyanttools.org. Bersumber dari lima hasil pencarian teratas yang berjumlah 3.913 kata kegiatan ini menemukan sepuluh tren berkaitan dengan hari tersebut. Kesepuluh tren itu adalah Kartini (153), perempuan (36), surat (33), Belanda (25), Jawa (22), Rembang (16), Jepara (15), emansipasi (9), Abendanon (8), serta Deventer (7).

Tidak hanya menunjukkan kuantitas, temuan itu sekaligus menjadi representasi memori kolektif sekaligus hafalan masyarakat tentang sosok bangsawan perempuan Jepara yang aktif menyuarakan emansipasi Bumiputra dengan surat-suratnya berbahasa Belanda. Padahal, hafalan menurunkan derajat manusia dan bertentangan dengan hakikat belajar sejarah, yaitu memperkenalkan manusia yang pernah berjuang kepada manusia yang sedang berjuang (Ali 2005:2,6). Dalam konteks inilah, kami ingin menghadirkan perjuangan Kartini dari situasi dan persoalan kontekstual di dunia 
pendidikan yaitu elaborasi revolusi industri 4.0, disrupsi teknologi, serta pendidikan niridentitas. Persoalan terakhir ini terutama terlihat dari ragam metode ataupun aliran dan kurikulum pendidikan yang diadopsi di Indonesia. Misalnya saja, HOTS (Higher Order Thinking Skills), STEM (Science, technology, engineering, and mathematics) yang direvisi menjadi STEAM (Science, technology, engineering, arts, and mathematics) lalu STREAM (Science, technology, research, engineering, and mathematics), serta kurikulum Montessori, Cambridge, Reggio Emilia, maupun 4C21CLD (critical thinking, creativity, communication, and collaboration for 21st Century Learning Design). Ketiga persoalan itu relevan dengan persoalan di zaman Kartini dan tawaran solusinya. Yaitu, liberalisasi ekonomi Hindia Belanda 1877, revolusi industri kedua, disrupsi teknologi, pandemi kolera 1902 yang telah menurunkan derajat bangsawan Jawa dan mendorong Kartini melakukan gerakan emansipasi Bumiputra melalui pendidikan (Mrazek, 2006:12; Sasi, 2020).

Gagasan pendidikan Kartini itu sekaligus dobrakan terhadap pendidikan arus utama Barat (Belanda). Ia memodifikasi pendidikan yang dianggapnya selaras dengan kondisi bangsawan Jawa, khususnya anak perempuan, tanpa menjadikan mereka setengah Belanda.

Kami sekali-kali ta' soeka akan mendjadikan moerid-moerid kami setengah Belanda atau mendjadi Belanda Djawa dengan pendidikan jang bebas itoe, ialah akan memboeat bangsa Djawa mendjadi Djawa jang sedjati jang berhati kasih dan tjinta kepada tanah dan bangsanja, lagi bermata dan berhati terang akan kebagoesan dan kesengsaraan bangsanja! Kami hendak memberikan kepadanja adat tertib-sopan orang Eropah, dengan tiada hendak memboeangkan adatnja sendiri (Pane, 1922:227-228).

Persoalannya kemudian adalah pendidikan Kartini hanya berlangsung tujuh bulan saja. Ia mati muda, lima hari setelah melahirkan (21 April 1879 -17 September 1904). Memang, kematiannya yang tragis mampu menggerakkan banyak orang untuk mewujudkan cita-citanya. Salah satunya adalah Jacques Henrij Abendanon yang tergerak menerbitkan surat-surat Kartini untuk menghimpun dana. Mengutip Abendanon, penghasilan yang diperoleh dari hasil penjualan buku kumpulan surat-surat tersebut akan digunakannya untuk mendirikan sekolah gadis bangsawan dengan kurikulum yang diinginkan Kartini (Pane, 1922:v).

Sekolah Kartini di Semarang adalah sekolah pertama yang berhasil didirikan dengan mekanisme tersebut. Hal ini sekaligus mendatangkan ganjalan. Pertama, jika cita-cita Kartini adalah mempertinggi derajat bangsa Jawa tanpa meninggalkan identitas kejawaannya dan Sekolah Kartini di Semarang yang berdiri pada 1912 itu dibuat untuk meneruskan cita-cita Kartini, tentunya sekolah tersebut dibangun untuk mempertinggi derajat bangsa Jawa tanpa meninggalkan identitas kejawaannya. Permasalahannya adalah guru-guru di sekolah tersebut adalah perempuan-perempuan Belanda. Hal ini menimbulkan pertanyaan sekolah macam apa yang bercita-cita menjaga identitas etnisitasnya jika pengelolaannya dilakukan oleh etnis bahkan ras yang berbeda dan dengan bahasa yang berbeda (Belanda). Kedua, sekolah ini mendapatkan sentimen yang relatif kurang baik. Ki Hajar Dewantara, misalnya, menyebut sekolah ini sebagai sekolah coba-coba yang tidak serius memajukan derajat bangsa (Majelis Luhur Persatuan Taman Siswa Yogyakarta, 2011:515).

Penelitian ini fokus pada permainan anak yang ada di sekolah Kartini sebagai salah satu media pendidikannya. Adapun pertanyaan penelitiannya ada tiga, yaitu: (1) jenis jenis permainan anak apa yang diajarkan di Sekolah Kartini Semarang? (2) apakah itu diajarkan dalam bahasa Belanda? (3) apakah itu memiliki esensi sama dengan nilai-nilai aslinya atau mengalami modifikasi dan modernisasi? Penelusuran, kajian, dan analisis terhadap ketiga hal tersebut diharapkan mampu memberikan perspektif baru dalam kajian sejarah pendidikan dan intelektual serta pengembangan media pembelajaran.

\section{KAJIAN PUSTAKA}

Era disrupsi teknologi dianggap mengikis nilai-nilai luhur budaya bangsa. Fenomena itu terlihat dari keberadaan nilai kearifan masyarakat yang pudar dan tereduksi dalam gaya hidup instan (Yulita, 2017:vi). Hal ini tidak hanya terjadi tidak hanya pada orang dewasa melainkan juga anak-anak yang cenderung pragmatis karena lebih akrab dengan gawainya dibandingkan bermain dengan realitas yang ada di sekitarnya. Situasi ini sekaligus "menggeser kedudukan permainan tradisional, sehingga menimbulkan efek negatif terhadap perkembangan anak, baik secara fisik, psikis, dan sosial (Praja, Nurfaidah\&Rahmiati, 2018:104). 
Keberadaan permainan anak di tengah disrupsi teknologi dan revolusi industri membuat pemerintah membuat peraturan khusus. Melalui Undang-undang Republik Indonesia Nomor 5 Tahun 2017, permainan tradisional, tradisi lisan, manuskrip, adat-istiadat, ritus, pengetahuan tradisional, teknologi tradisional, seni, bahasa, permainan rakyat, serta olahraga tradisional menjadi objek pemajuan kebudayaan nasional. Hal ini dilakukan dengan beragam tujuan. Di antaranya adalah mengembangkan nilai-nilai luhur budaya bangsa, memperkaya keberagaman budaya, memperteguh jati diri bangsa serta persatuan dan kesatuan bangsa, mencerdaskan kehidupan bangsa, meningkatkan citra bangsa, mewujudkan masyarakat madani, meningkatkan kesejahteraan rakyat, melestarikan warisan budaya bangsa, serta mempengaruhi arah perkembangan peradaban dunia (Kementerian Pendidikan dan Kebudayaan, 2017).

Fenomena tergesernya permainan anak juga memunculkan komunitas yang memiliki kepedulian terhadap hal ini (Anonim, 2010; Aditya 2016). Di lain sisi, permainan anak juga dimasukkan sebagai bagian pembelajaran STEAM pada pendidikan anak usia dini serta pendidikan dasar. Tidak ketinggalan, program "Belajar Dari Rumah" yang digagas oleh Kementerian Pendidikan dan Kebudayaan di tengah pandemi juga turut menyosialisasikan kembali ragam permainan tradisional yang mulai tidak dikenali oleh anak-anak (Anam, 2020; Febrida, 2020; Nurchamim, 2020). Hal ini sekaligus menumbuhkan harapan di tengah penutupan Museum Anak Kolong Tangga yang mewadahi permainan tradisional anak.

Di lain sisi, kajian permainan juga terus dilakukan. Namun, penulisannya dapat dibedakan menjadi enam, yaitu (1) penyebaran agama Islam melalui permainan tradisional, (2) makna permainan anak, (3) manfaat permainan tradisional sebagai pembentuk karakter ataupun meningkatkan kecerdasan kognitif, sosial, serta motorik, (4) jenis-jenis permainan tradisional, (5) filosofi permainan tradisioanal yang bersumber dari pemikiran Dewantara, serta (6) permainan tradisional di tengah disrupsi teknologi (Adi, Sudaryanti\&Mutmainnah, 2020:36-38; Andriani, 2012:127-134; Paaneah, Sunardi, Wuryani, 2019:142-143; Saputra\&Ekawati, 2017:47-48; Setiawan, 2020:12; Wijayanti, 2014:52-55).

Dari uraian-uraian di atas dapat digarisbawahi bahwa kajian permainan anak di Indonesia selalu berkaitan dengan dua hal. Kedua hal yang dimaksud adalah penyematan lema tradisional dalam jenis permainan anak dan penekanan bahwa jenis permainan ini telah tergeser oleh teknologi dan menjadi penyebab lunturnya nilai-nilai luhur dan kepribadian bangsa. Padahal, hal itu berlawanan dengan pendapat utuh Ki Hajar Dewantara tentang hakikat permainan anak yang selalu dijadikan sebagai sumber rujukan. Pendiri Taman Siswa ini menekankan adanya kontinuitas dan evolusi yang relatif luput dari kacamata peneliti (Majelis Luhur Persatuan Taman Siswa Yogyakarta, 2011:243-244).

Tulisan ini akan mengadopsi kontinuitas dan evolusi dalam permainan anak yang dikemukakan oleh Dewantara sebagai dasar kerangka konseptual. Namun, tidak menutup peluang untuk mencari konsep yang sesuai. Hal ini disebabkan Sekolah Kartini Semarang hadir satu dasawarsa lebih dahulu dibandingkan pemikiran Dewantara tentang Perguruan Nasional Taman Siswa.

\section{METODE PENELITIAN}

Fenomena permainan anak di Sekolah Kartini Semarang akan dikaji dengan metode sejarah mentalitas. Sejarah ini adalah bagian dari cabang sejarah yang mendalami perihal kesadaran masyarakat, menghadirkan ketidaksadaran kolektif (Kuntowijoyo, 2005:237, 244). Dalam konteks ini, penelitian mula-mula dilakukan dengan pengumpulan sumber, meliputi mengumpulkan laporan tahunan dan album kenangan Sekolah Kartini Semarang 1914-1939, arsip pemerintah, serta literatur dari penelitian di Arsip Nasional Republik Indonesia Jakarta dan Dinas Perpustakaan dan Arsip Provinsi Jawa Tengah. Selain itu, peneliti juga melakukan penelitian di Museum Perjuangan Wanita, Museum Kolong Anak, dan Yayasan van Deventer di Yogyakarta serta Yayasan Kartini. Berikutnya, analisis data dilakukan pendekatan yang disebut verstehen (memahami). Pendekatan ini menempatkan subjek manusia sebagai fokus serta makna subjektifnya. Dengan demikian, kajian tentang permainan anak bukan fokus pada jenis permainannya melainkan anak-anak yang bermain, pemaknaan mereka tentang permainan, serta bentuk-bentuk ketidaksadaran kolektif dalam aktivitas tersebut. Terakhir, hasil analisis tersebut diinterpretasi dengan pendekatan imajinasi sejarah. Mengutip Kuntowijoyo (2003:247) pendekatan ini menghadirkan konteks dan struktur zaman yang diteliti. Dalam konteks ini, metode khusus itu akan menangkap ekspresi serta refleksi konstruksi sosial yang tidak bisa dilukiskan oleh sumber-sumber tekstual. 


\section{HASIL PENELITIAN DAN PEMBAHASAN}

\section{Hasil Penelitian}

Gagasan pendirian Sekolah Kartini disebarluaskan oleh H. Abendanon sejak 1911. Sekalipun demikian, pendirian secara definitif Sekolah Kartini Semarang baru dimulai seiring dengan kedatangan Van Deventer yang mengususng pendidikan perempuan dan pendirian Sekolah Kartini dalam pertemuan di Semarang pada Agustus 1912 (Anonim 1914). Sebuah komisi beranggotakan H.C.A.G. de Vogel (Residen Semarang), Mas Adipati Ario Poerboadiningrat (bupati Semarang), J.L. van Houten, Maclaine Pont-Gerling, dan H. Baron dibentuk untuk merealisasikan dua gagasan tersebut (Anonim, 1915).

Pembentukan panitia pokok tersebut diikuti dengan pembentukan panitia pelaksana. Z. Stockvis, Cohen Stuart Wallbrink-Krisfield (istri Stockvis), Raden Ajoe Sosrohadikoesoemo, Raden Kamil, Raden Mas Soenarto, Atmodirono, Mas Mangoenkoesoemo, serta H. Maclain Pont adalah nama-nama yang bekerja di balik kepanitiaan ini. Selanjutnya, kepanitian ini diresmikan dengan nama Kartinivereeniging in Nederlandsch-Indie dengan keputusan pemerintah 28 Maret 1913 No. 16. Pembentukan organisasi ini kemudian diikuti dengan pembentukan organisasi pencari dana, yaitu Kartinifond yang dipimpin oleh van Deventer dan H. Abendanon. Di tahun pertama, organisasi ini mengumpulkan 331 donatur, terdiri dari 141 kelompok Eropa, 189 Bumiputra, dan 1 Tionghoa (Anonim 1915). Enam bulan kemudian, sekolah yang dicita-citakan berhasil direalisasikan pada 15 September 1913. Sekolah ini mula-mula menyewa sebuah rumah di Djombangweg sebelum akhirnya pindah secara permanen pada 10 Desember 1913. Sebuah lahan di Karrenweg seluas $17.275 \mathrm{~m} 2$ menjadi area sekolah. Adapun pembangunannya menghabiskan f 2.659, 375 (dua ribu enam ratus lima puluh sembilan gulden, tiga puluh tujuh setengah sen).

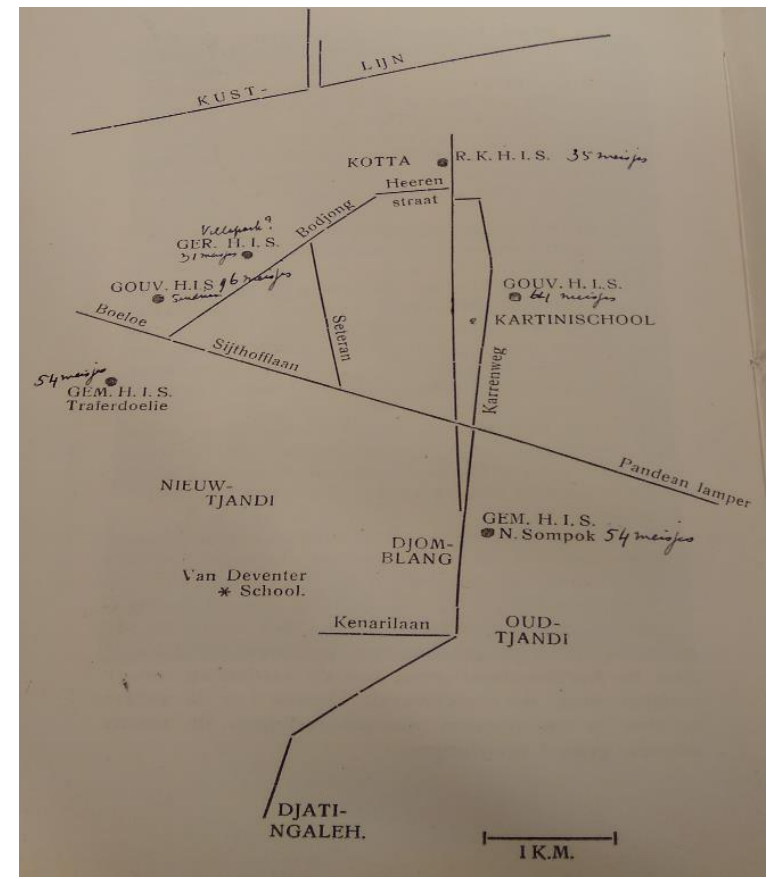

Gambar 2. Peta lokasi Sekolah Kartini

Sumber: Anonim (1926)

Sekolah Kartini Semarang menganut aliran pendidikan Froebel. Dengan demikian, gurugurunya pun memiliki kriteria khusus yaitu perempuan lulusan pendidikan guru Froebel dari Belanda sebagai guru utama dan perempuan lulusan Sekolah Guru Froebel di Hindia Belanda sebagai guru bantu. Berikutnya, permainan anak sebagai salah satu penciri aliran Froebel diberikan diajarkan di kelas I-III melalui mata pelajaran vrije en orde oefeningen (latihan kebebasan dan ketertiban) dengan durasi masing-masing $1 \frac{1}{2}, 1$, dan 3/4 jam (Anonim, 1915). Tidak ada informasi jelas tentang jenis permainan apa yang dimainkan murid-murid di tiga kelas tersebut juga kelas persiapan. Satu-satunya informasi adalah permainan kembang asam (Anonim, 1925). 
Sekalipun tidak ada informasi tentang jenis permainannya, foto-foto pada Gambar 3B memberikan informasi bahwa permainan di Sekolah Kartini mengutamakan gerak, baik gerak dengan ritme maupun bebas. Selain itu ada pula kerajinan tangan (menganyam) atau duduk-duduk beristirahat maupun mengamati kondisi sekitarnya. Mulai bermain dengan burung-burung merpati maupun bercengkrama dengan ikan mas.

Terlepas dari keterbatasan informasi tentang jenis permainan dan cara memainkannya, fotofoto permainan anak di Sekolah Kartini Semarang juga menampilkan sosok guru dalam posisi yang hampir sama. Dalam hal ini, kesepuluh foto tersebut menampilkan hal sama yaitu guru-guru yang tampak mengawasi baik dalam posisi berdiri maupun duduk. Keberadaan foto sebagai dokumentasi barangkali bisa dianggap sebagai pemakluman keberadaan guru-guru lulusan Froebel. Sekalipun demikian, jika dikembalikan kepada konteksnya, bahwa foto-foto itu bukan tentang tentang permainan atau kegiatan bermain melainkan pelajaran tentang latihan kebebasan dan ketertiban, keberadaan guru kiranya dapat dipandang sebagai penjamin atau pemandu.
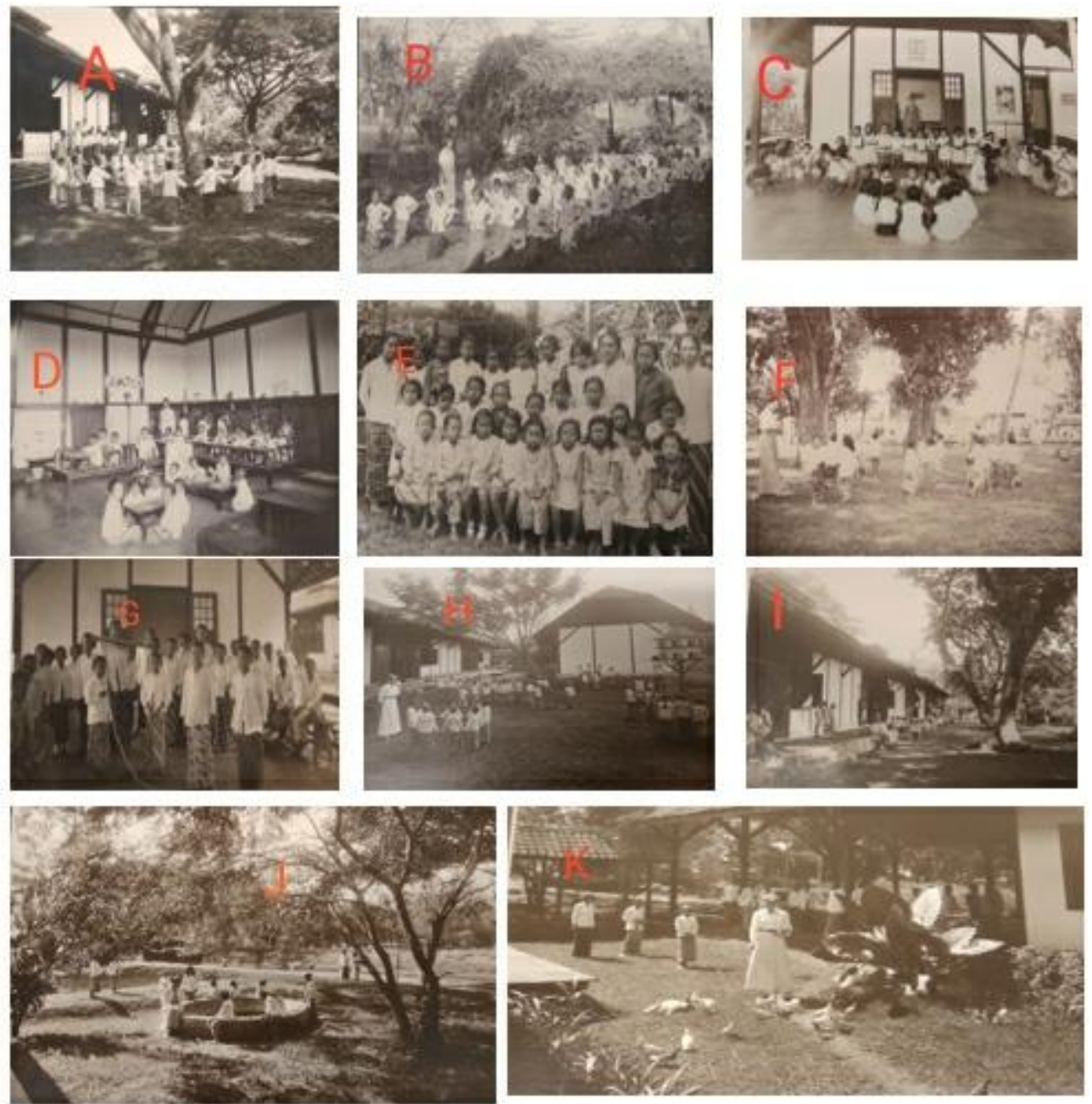

Gambar 3. Aktivitas bermain

Sumber: Anonim (1925)

Gambar 3E menjadi pengecualian. Di sana guru dan murid tidak sedang beraktivitas bermain. Namun, keterangan di bawah foto memberikan realitas yang menarik. Pertama, foto tersebut adalah foto bersama yang dibuat sesaat setelah latihan kebebasan dan ketertiban. Foto tersebut menggambarkan 25 murid kelas persiapan A ( 9 anak dalam posisi duduk, 9 berdiri, dan 7 berdiri di atas bangku). Adapun guru yang mendampinginya adalah Sriambaryah (guru bantu lulusan Froebel) serta tiga calon guru bantu. Kedua, murid-murid itu tidak hanya mengenakan kain melainkan gaun. Enam dari sembilan anak yang duduk tidak lagi bertelanjang kaki, melainkan telah bersepatu. Sepatu adalah simbol kehidupan modern sekaligus penunjuk hierarki status sosial dan bagian dari busana kaum 
intelektual urban di Hindia Belanda pada tahun 1920-an, serta penanda perbedaan kaya dan miskin, urban ataupun desa (Nordholt, 2005:35-37). Dengan demikian, foto anak-anak ini adalah representasi kehidupan orang tua mereka. Berikutnya, foto ini menjadi menarik karena untuk pertama kalinya sekolah menerapkan kebijakan mengenakan celana pendek di bawah kain. Modifikasi ini dilakukan dengan pertimbangan agar anak-anak lebih bebas bergerak.

Permainan anak tidak hanya menjadi bagian kurikulum. Itu juga (di)hadir(kan) dalam pentas tahunan. Informasi tentang hal ini salah satunya dibukukan dalam buku teks perayaan ulang tahun sekolah yang kelima, Minggu 15 September 1918. Ada tiga permainan yang ditampilkan, yaitu: hoe de kleine muisjes gewroken hebben (bagaimana tikus-tikus kecil itu terbangun); loeroe loeroe widoro, serta paman doblang (Anonim, 1918). Ketiga permainan tersebut dimainkan dengan gerak dan lagu dan dinyanyikan dwibahasa (Belanda-Jawa).

Permainan pertama menceritakan tentang bagaimana tikus kecil di sudut gelap di rumah, terbangun lalu berlari-lari karena dikejar-kejar oleh kucing. Kegiatan berkejar-kejaran itu disertai dengan dialog bahasa Belanda. Selanjutnya, ketika tertangkap oleh kucing, ada dialog bahasa Jawa dan dilanjutkan dengan bahasa Belanda.

$\begin{array}{ll}\text { ngoendjoek limoen, raden? } & \text { wil je limonade drinken? } \\ \text { enak, seger? } & \text { lekker, frisch? } \\ \text { dahar kroket, raden? } & \text { wil je croquetjes hebben? } \\ \text { timblang, tembleng } & \text { hap, snap } \\ \text { dahar banket raden? } & \text { wil je koekjes hebben } \\ \text { kremes-kremes } & \text { (geluid) }\end{array}$

Jika diperhatikan, dialog-dialog tersebut adalah dilakukan ketika anak-anak telah selesai berkejar-kejaran dan memutuskan untuk minum es jeruk serta makan cemilan berupa kroket dan kuekue kering.. Namun, tidak sekadar menirukan aktivitas minum dan makan setelah kelelahan, mereka juga belajar kondisi, cara minum dan santap, serta suara-suara yang dihasilkan dari kegiatan minum dan makan tersebut. Contohnya, enak dan kesegaran es jeruk, isian kroket yang muncrat ketika digigit, serta kue kering renyah yang jika digigit menciptakan suara kremes-kremes. Lebih lanjut, dialog-dialog dalam permainan gerak dan lagu ini mirip dengan permainan anak kucing-kucingan. Hanya saja, di Jawa, permainan tersebut kini sudah tidak memiliki dialog.

Sementara itu, permainan loeroe, loeroe widoro dibawakan dalam bahasa Jawa dan diulang dalam bahasa Belanda.

\begin{tabular}{|c|c|}
\hline $\begin{array}{l}\text { loeroe, loeroe widoro } \\
\text { widarane lagi opo } \\
\text { widarane lagi semi } \\
\text { ajo podo nyiramie }\end{array}$ & $\begin{array}{l}\text { laten wij zoeken widoro } \\
\text { hoe is de widoro? } \\
\text { de widoro is aan de 't ontspruitten } \\
\text { kom laten wij ze begieten }\end{array}$ \\
\hline $\begin{array}{l}\text { loeroe, loeroe widoro } \\
\text { widarane lagi opo } \\
\text { widarane lagi kembang } \\
\text { ajo podo geloeng malang }\end{array}$ & $\begin{array}{l}\text { laten wij widoro zoeken } \\
\text { hoe is de widoro? } \\
\text { de widoro is aan 't bloeien } \\
\text { kom, streekt de bloemen in het haar }\end{array}$ \\
\hline $\begin{array}{l}\text { loeroe, loeroe widoro } \\
\text { widarane lagi opo } \\
\text { widarane lagi pentil } \\
\text { ajo podo brongsongi }\end{array}$ & $\begin{array}{l}\text { laten wij widoro zoeken } \\
\text { hoe is de widoro? } \\
\text { de widoro heeft vrucht gezet } \\
\text { kom laten wij er maandjes om doen }\end{array}$ \\
\hline $\begin{array}{l}\text { loeroe, loeroe widoro } \\
\text { widarane lagi opo } \\
\text { widarane lagi njadham } \\
\text { ajo, podo ngroedjak enak }\end{array}$ & $\begin{array}{l}\text { laten wij widoro zoeken } \\
\text { hoe is de widoro? } \\
\text { de widoro 's zijn half rijp } \\
\text { kom laten wij lekkere roedjak maker }\end{array}$ \\
\hline
\end{tabular}


loeroe, loeroe widoro widarane lagi opo widarane uwis mateng ajo podo ngoendoehi

taq kandoet: mroetjoet tak gimbol: mrodjol adoe bijoeng, betjaq eri laten wij widoro zoeken

hoe is de widoro?

de widoro 's zijn rijp

kom laten wij ze plukken

ik doe ze is mijn baadjes: ze vallen er uit ik doe in mijn kain; ze vallen er ook uit au, au, au ik heb in een doorn getraapt

Widoro atau bidara (Ziziphus mauritiana) adalah tanaman semak, berbentuk seperti apel dan kecil-kecil. Dengan demikian, permainan loeroe-loeroe widoro adalah peniruan akan gambaran aktivitas keseharian anak-anak mencari buah tersebut. Tidak hanya meniru, permainan itu yang disertai dengan gerakan provokasi itu disertai dengan sisipan pengetahuan tentang proses pertumbuhan, cara perawatan, proses berbunga dan berbuah, serta pemanennya. Ketika widoro semi (bersemi), misalnya, anak-anak beramai-ramai menyirami, ketika berbunga, mereka mengambil bunga yang berjatuhan dan menyisipkannya di gelungan (jalinan rambut). Begitu juga ketika pohon telah mulai berbuah, mereka brongsongi (membungkus buah) agar terhindar dari hewan-hewan pengganggu. Sementara ketika buah sudah setengah matang, mereka memetiknya dan menjadikannya sebagai rujak. Terakhir, ketika sudah masak, mereka beramai-ramai memanennya. Namun, proses memanen lalu membawanya pulang itu bukan perkara mudah. Ketika dikandut (dimasukkan ke dalam kemben) ataupun digimbol (dibuntel) dengan ujung kain ternyata jatuh. Selanjutnya, karena terlalu fokus, mereka tidak sadar jika tertusuk duri sehingga menangis dan memanggil biyung (ibu).

Permainan terakhir yang tertulis adalah paman doblang. Permainan gerak dan lagu ini menceritakan dialog anak-anak dengan orang lebih tua yang disapa dengan panggilan paman doblang seputar gadung (Dioscorea hispida). Lagu ini ditampilkan dalam dua bahasa disertai dengan penjelasan tentang gadung sebagai een knol die bedwelmt, als men er te veel van eet (umbi yang memabukkan, apabila dimakan terlalu banyak).

man dobloang

he!

rekane wong ndoedog gadoeng nikoe pripoen?

man doblang, paman doblang

ngih meketen

rekane wong ngontjeqi gadoeng

nikoe pripoen?

man doblang nggih meketen

rekane wong ngoembah gadoeng

nikoe pripoen?

man doblang nggih meketen

rekane wong nggodok gadoeng

nikoe pripoen?

man doblang nggih meketen man doblang!

ja.

hoe doet iemand, die gadoeng uit de grond graaft? zoo graaft man doblang

hoe doet iemand, die gadoeng schilt? zoo schilt man doblang

hoe doet iemand, die gadoeng wascht? zoo wascht man doblang

hoe doet iemand, die gadoeng kookt? zoo kookt man doblang

Tidak hanya berisi peniruan pengolahan gadung, permainan gerak dan lagu paman doblang itu sarat makna. Pertama, gadung adalah umbi-umbian yang tumbuh dan dapat ditemukan di kebun ataupun pekarangan masyarakat Jawa. Itu biasanya dijadikan bahan pangan terutama di musim kemarau 
untuk dijadikan sebagai pengganti nasi atau dapat diolah menjadi kerupuk gurih. Akan tetapi, proses nduduk (memanen dengan menggali) hingga mengolahnya menjadi makanan jadi bukanlah perkara mudah. Gadung adalah tanaman merambat berduri tajam, besar-besar, sangat rapat, dan menjadi tempat persembunyian kalajengking beracun. Sementara umbinya mengandung sianida (wawancara, 2020). Kedua, gerak dan lagu cara mendapatkan umbi gadung dan pengolahannya menjadi makanan jadi tidak hanya menceritakan tidak hanya berisi tentang peniruan kegiatan sehari-hari. Lebih dari itu, ada transfer pengetahuan pangan di sana.

\section{Pembahasan}

Sekolah Kartini Semarang adalah salah satu penganut penganut aliran pendidikan Froebel. Aliran ini berpendapat bahwa pendidikan anak harus dilaksanakan sesuai dengan kodrat anak, yaitu bergerak dan berfantasi (Majelis Luhur Persatuan Taman Siswa Yogyakarta, 2011:252). Adapun medianya adalah bermainan. Mengutip Friedrich Froebel, sang pencetus, permainan sangat penting bagi anak-anak karena membentuk kreativitas. Di lain sisi, permainan untuk anak-anak juga serupa pekerjaan bagi orang dewasa (Palmer, 1912:75; Wilson, 1964:218).

Dalam bukunya yang berjudul Die Menschenerziehung (The Education of Man), terbit pertama 1826), Froebel secara khusus menulis bahwa kajian tentang permainan telah banyak. Namun, ia hendak menambahkan hal-hal yang belum dikaji, yaitu pembagian permainan anak menjadi tiga. Ketiga kategori yang dimaksud adalah (1) tiruan kehidupan dan fenomena kehidupan sosial, (2) aplikasi spontan dari apa yang telah dipelajari di sekolah, serta (3) produk pikiran yang spontan sempurna, deskripsi apa pun, dan dengan semua jenis material. Selanjutnya, ia menambahkan bahwa bagian yang terakhir ini memiliki tujuan khusus, yaitu mencari hukum yang ada dalam materi permainan, atau mereka mematuhi hukum yang ada dalam pikiran dan perasaan manusia, dalam setiap kasus. Dengan demikian, permainan anak adalah hasil murni dari energi vital dan kegembiraan anak serta cerminan kehidupan batin dan kekuatan-kehidupan eksternal yang sebenarnya. Jika ini kurang, tidak mungkin ada permainan sejati yang, dengan sendirinya penuh dengan kehidupan asli, dapat membangkitkan, memberi makan, dan mengangkat kehidupan (Froebel, 1887:302).

Berikutnya, Froebel menambahkan bahwa permainan anak mencakup permainan fisik, baik latihan kekuatan dan ketangkasan, atau sekadar ekspresi kegembiraan jiwa; permainan akal; latihan pancaindera; atau permainan intelektual, melatih perhatian dan penilaian. Semua permainan itu dilakukan di bawah bimbingan khusus, yaitu guru (Froebel, 1826:303-304). Dengan demikian, sekolah froebelian (penganut aliran Froebel) menempatkan guru sebagai penjamin agar permainan anak di sekolah mampu meledakkan kegembiraan anak karena kegembiraan adalah kegembiraan adalah jiwa dari setiap aktivitas (Froebel, 1887:304).

Sekolah Kartini Semarang adalah sekolah beraliran Frobel di Hindia Belanda. Pengaruh Froebel ini tidak hanya tampak dari keberadaan guru-guru yang semuanya lulusan pendidikan sekolah guru Froebel, melainkan juga dari kurikulumnya. Salah satunya terlihat dari mata pelajaran latihan kebebasan dan ketertiban yang diberikan untuk murid-murid kelas persiapan serta kelas I-III. Dengan kata lain, anak-anak di keempat kelas tersebut didorong untuk mendapatkan kebebasan penuh sekaligus latihan untuk tertib atau taat pada aturan (hukum).

Dalam kerangka pemikiran Froebelian pula, permainan bukan lagi sebagai pendidikan karakter atau penerapan nilai-nilai tradisi. Permainan adalah pekerjaan anak-anak, alat untuk mencapai kegembiraan. Misalnya saja melalui permainan fisik, baik latihan kekuatan dan ketangkasan, atau sekadar ekspresi kegembiraan jiwa; permainan akal; latihan pancaindera; atau permainan intelektual serta latihan perhatian dan penilaian sebagaimana tampak dalam Gambar 3, serta permainan hoe de kleine muisje gewokken hebben. Sementara itu, permainan loeroe loeroe widoro atau paman doblang adalah permainan yang disebut Froebel sebagai tiruan kehidupan dan fenomena kehidupan sosial.

Spontanitas adalah unsur utama dalam permainan yang dikembangkan oleh Sekolah Froebel. Dalam hal ini, anak-anak diberi keleluasaan untuk melakukan aktivitasnya. Mulai dari duduk-duduk, memberi makan merpati, maupun bercengkrama dengan ikan mas. Lebih lanjut, spontanitas juga ditumbuhkan melalui kebebasan untuk melakukan pengamatan, bereaksi terhadap hal-hal yang diamati, serta keputusan selama pengamatan. Sementara itu, kehadiran guru-guru di dalam suasana bermainan adalah sebagai pemandu. Guru menjamin anak-anak bisa bergembira dan memiliki kepercayaan diri untuk memilih ragam permainan yang disukai, bermain, dan bersosialisasi bersama teman-temannya. 


\section{SIMPULAN DAN SARAN}

\section{Simpulan}

Dari uraian-uraian di atas dapat disimpulkan bahwa permainan anak di Sekolah Kartini Semarang dikembangkan sesuai dengan aliran pendidikan Froebel. Mengikuti aliran ini, sekolah didesain menjadi taman bermain anak-anak dan setiap hal adalah permainan. Oleh karena itu, permainan tidak dibatasi pada jenis, filosofi, maupun manfaatnya bagi tumbuh kembang anak. Lebih penting dari semua hal itu, orientasi permainan adalah gerak dan fantasi anak-anak melalui peniruan kehidupan sehari-hari maupun fenomena sosial, tindakan spontan, serta pemikiran spontan dengan semua material yang ada di dalam sekolah. Ketiga hal ini membuat permainan anak di Sekolah Kartini bersifat universal. Permainan anak Jawa berpadu dengan permainan anak dari Belanda yang diajarkan oleh "guru-guru impor" dari Belanda. Dengan demikian, permainan anak di sini dibawakan dalam bahasa Jawa dan bahasa Belanda. Dwibahasa juga berlaku ketika anak-anak memilih permainan permainan fantasi melalui pengamatan. Sementara guru-guru ikut hadir untuk memandu anak-anak untuk bergembira. Pengenalan bahasa ini sekaligus simbol modernitas kelompok urban elite di masa kolonial Hindia Belanda.

Berikutnya, permainan anak di Sekolah Kartini tidak hanya dilakukan saat istirahat. Permainan termasuk kurikulum, secara khusus termasuk pelajaran latihan kebebasan dan ketertiban, yang diwajibkan untuk kelas I-III serta kelas persiapan. Adapun durasinya berbeda-beda sesuai dengan dengan jenjang kelas. Dalam konteks inilah, kajian permainan anak di Sekolah Kartini bukan lagi tentang pergeseran filosofi Jawa maupun bentuk modifikasi dan modernisasi. Sebaliknya, permainan di sekolah ini dapat dibaca sebagai reformasi pendidikan di tengah revolusi industri 2.0 yang dipengaruhi oleh pemikiran Froebel. Di lain sisi, Sekolah Kartini juga menjadi salah satu contoh sekolah beraliran Froebel pertama di Hindia Belanda.

\section{Saran}

Sebuah kajian holistik tentang permainan anak dibutuhkan tidak hanya untuk menempatkan permainan anak sebagai bagian dari sejarah pendidikan dan intelektual di Indonesia, melainkan juga bagian dari pencarian identitas roh pendidikan Indonesia. Dalam konteks ini, sejarawan dan pendidik pendidikan dasar maupun anak usia dini harus memulai kerja kolaborasi.

Berikutnya, kajian tentang Sekolah Kartini selalu dikaitkan dengan politik etis atau politik balas budi. Sementara istilah Sekolah Kartini juga acap kali disamakan dengan Sekolah van Deventer. Tulisan ini telah mendapati temuan bahwa kedua sekolah itu adalah sekolah yang berbeda. Sementara perspektif yang berbeda berhasil mendapatkan temuan tentang pengaruh pemikiran Froebel. Kedua hal ini menumbuhkan pemikiran tentang perlunya kajian-kajian lebih lanjut tentang Sekolah Kartini dengan ragam perspektif serta pelacakan pengaruh pemikiran Froebel bagi pendidikan di Indonesia, khususnya di Taman Kanak-Kanak maupun Sekolah Dasar kelas I-III. Jika hal ini dilakukan, sebuah gambaran historis tentang perkembangan pendidikan di Indonesia dapat dipetakan dengan jelas. Dengan demikian, kerja-kerja merumuskan identitas pendidikan Indonesia bukanlah hal sulit. Terakhir, kajian permainan anak biasanya senantiasa selalu dikaitkan dengan permainan tradisional. Melalui kajian ini, penulis ingin menumbuhkan kembali kesadaran historis pembaca untuk melihat anak sebagai subjek belajar serta dinamika masyarakat sesuai dengan konteks zaman.[]

\section{UCAPAN TERIMAKASIH}

Tulisan ini terwujud dengan bantuan dana penelitian internal Universitas Kristen Satya Wacana Oktober-Desember 2020. Oleh karena itu, penulis mengucapkan terima kasih kepada para pimpinan yang terus mendorong kami untuk terus menghidupi garba ilmiah.

\section{DAFTAR PUSTAKA}

Adi, B. S., Sudaryanti, \& Muthmainnah. (2020). Implementasi Permainan Tradisional dalam Pembelajaran Anak Usia Dini sebagai Pembentuk Karakter Bangsa. Jurnal Pendidikan Anak., 9(1). https://doi.org/https://doi.org/10.21831/jpa.v9i1.31375. 
Aditya, R. (2016). Bikin Kecewa! 7 Permainan Zaman SD Ini Sudah Punah Tergusur Gadget. Tribunnews.Com. https://style.tribunnews.com/amp/2016/10/23/bikin-kecewa-7-permainanzaman-sd-ini-sudah-punah-tergusur-gadget?page=all.

Anam, C. (2020). Permainan Tradisional Alternatif Hiburan bagi Anak di Masa Pandemi Covid-19. https://surabaya.bisnis.com/read/20200724/531/1270836/permainan-tradisional-alternatifhiburan-bagi-anak-di-masa-pandemi-covid-19.

Anonim. (2020). Hari Penting. Perpustakaan Nasional Republik Indonesia. https://www.perpusnas.go.id/directory.php?lang=id.

Anonim. (1915). Eerste Jaarverslag der Kartini Vereeniging in Nederlandsch-Indie. G.C.T. van Dorp \& Co.

Anonim. (1925). Kartinischool 1925.

Anonim. (1918). Programma en Tekstboekje van de Feestavond ter Herdenking van het Vijfjarig Bestaan de School. Kartini School der Semarang.

Anonim. (1926). Elfde Jaarverslag der Kartini Vereeniging in Nederlandsch-Indie. G.C.T. van Dorp \& Co.

Anonim. (2010). Permainan Anak Tradisional Makin Tergusur. Koran Tempo. https://koran.tempo.co/amp/berita-utama-jateng/213662/permainan-anak-tradisional-makintergusur.

Febrida, M. (2020). 5 Permainan yang Bikin Anak Lincah Tetap Aktif Selama Pandemi. Haibunda.Com. https://www.haibunda.com/parenting/20200814094754-61-156842/5-permainan-yang-bikinanak-lincah-tetap-aktif-selama-pandemi.

Froebel, F. W. A. (1887). The Education of Man. D. Applenton and Company.

Kementerian Pendidikan dan Kebudayaan. (2017). Salinan Undang-undang Republik Indonesia Nomor 5 Tahun 2017. Kementerian Pendidikan Dan Kebudayaan. https://kebudayaan.kemdikbud.go.id/wp-content/uploads/2017/11/UU-No-5-Tahun-2017tentang-Pemajuan-Kebudayaan.pdf.

Kuntowijoyo. (2005). Metodologi Sejarah Edisi Kedua. Tiara Wacana.

Majelis Luhur Persatuan Taman Siswa Yogyakarta. (2011). Karya Ki Hajar Dewantara Bagian Pertama. Majelis Luhur Persatuan Taman Siswa Yogyakarta.

Mrazek, R. (2006). The Engineer of Happy Land: Perkembangan Teknologi dan Nasionalisme di Sebuah Koloni. Yayasan Obor Indonesia.

Nordholt, H. S. (2005). Outward Appearances: Trend, Identitas, Kepentingan. LKIS.

Nurchamim. (2020). Peringatan Hari Anak Nasional di Masa Pandemi. Jawa Pos. https://www.jawapos.com/photo/peringatan-hari-anak-nasional-di-masa-pandemi.

Paaneah, D. Z., Sunardi, \& Wuryani, E. (2019). Pemahaman Syair Tembang Lir-Ilir Karya Sunan Kalijaga dalam Pembelajaran IPS Pada Siswa Kelas VII B SMP Kristen Satya Wacana Salatiga. Satya Widya, 35(2). https://doi.org/https://doi.org/10.24246/j.sw.2019.v35.i2.p140-147.

Palmer, L. A. (1912). Montessori and Froebelian Materials and Methods. The Elementary School Teacher, 13(2). https://www.jstor.org/stable/993497.

Pane, A. (1922). Habis Gelap Terbitlah Terang. Balai Pustaka.

Praja, A. L., Nurfaidah, S. S., \& Rahmiati, D. (2020). Penggunaan Sarana Belajar Melalui Permainan Tradisional dalam Membangun Nilai-Nilai Karakter Bangsa Di Sekolah Dasar. Trilogi. http://trilogi.ac.id/journal/ks/index.php/jpmikp. 
Modifikasi Atau Modernisasi (?): Permainan Anak di Sekolah Kartini Semarang

(Galuh Ambar Sasi, Emy Wuryani, Sunardi)

Saputra, N. E., \& Ekawati, Y. N. (2017). Permainan Tradisional Sebagai Upaya Meningkatkan Kemampuan Dasar Anak. Jurnal Psikologi Jambi, 2(2). https://onlinejournal.unja.ac.id/jpj/article/view/4796.

Sasi, G. A. (2020). “(Bukan) peringatan Kosong (?). In Dear Kartini. Iam Publishing.

Sasi, G. A. (2020). Kartini, Pandemi, dan Teologi.

Setiawan, Y. (2020). Pengembangan Model Pembelajaran Matematika SD Berbasis Permainan Tradisional Indonesia dan Pendekatan Matematika Realistik. Scholaria: Jurnal Pendidikan Dan Kebudayaan, 10(1). https://doi.org/https://doi.org/10.24246/j.js.2020.v10.i1.p12-21.

Wijayanti, R. (2014). Permainan Tradisional sebagai Media Pengembangan Kemampuan Sosial Anak. Cakrawala Dini, 5(1). https://doi.org/https://doi.org/10.17509/cd.v5i1.10496.

Wilson, S. (1967). The "Gifts" of Friedrich Froebel. Journal of the Society of Architectural Historians, 26(4). https://www.jstor.org/stable/988449).

Yulita, R. (2017). Permainan Tradisional Anak Nusantara. Badan Pengembangan dan Pembinaan Bahasa, Kementerian Pendidikan dan Kebudayaan. 